\title{
Gender Divide in Science: Breaking the Glass Ceiling
}

\author{
${ }^{1}$ Prof. Navaneeta Rath, ${ }^{2}$ Subhra Mishra \\ ${ }^{1}$ Department of Sociology, Utkal University, Bhubaneswar, Odisha \\ ${ }^{2}$ IInd Semester, Electrical Enginering, CET, Bhubaneswar
}

\begin{abstract}
Science is taken as the supreme branch of knowledge. It has become the driver of the knowledge economy. Women's empowerment is possible through the accommodation of women in science. But till date science education, scientific human resource, scientific leadership, scientific excellence recognition, scientific fellowship grants favour men much more than the women. Gender divide is sharp in science. This undermines the potentials and skill of women and challenges their participation in the knowledge society. Attractive policies have failed to accommodate more and more women in science. The present paper analyses the position of women in the scientific landscape of the country, makes a review of the literature relating to women's role in science, the existing policies protecting and promoting women's continuation in scientific professions, the current scenario and the challenging forces. Finally, it provides some viable interventions that can magnate women towards the scientific profession to break the glass ceiling.
\end{abstract}

Keywords: Gender divide, Glass ceiling, Marginalisation, Knowledge society, Scientific human resource, Scientific leadership.

Human civilization today dwells upon a knowledge society. Science, technology and innovation are the buzz words of a knowledge society. The Merriam-Webster dictionary ${ }^{1}$ defines Science as knowledge about or study of the natural world based on facts learned through experiments and observation. It is objective and based on experimental knowledge. The Oxford Dictionary ${ }^{2}$ defines innovation as a new method, idea, product, etc. Innovation creates an enabling and enriching environment for human beings to live in by easing their lives. Science forms the foundation and promotes innovation.

A knowledge society presupposes equal participation of all gender groups in science and innovation. Science is said to be evidenced based objective knowledge. So, it is said to be a potent empowering power for the people in general and women in particular. It is the chief resource of a knowledge society and is the anchor of the process of development. Without participation of people in science, the formation of a knowledge society becomes a myth.

Science as a branch of knowledge for a long time was highly patriarchal with the uneven representation of men and women. Masculine ethos and practices dominated science as a stream of knowledge and scientific institutions. Gender dogmas and gender stereotypes have long sidelined women from science. This is reflected through the under representation of women in the study of science and in scientific profession. It was believed that women lacked the superior brains, trainings, skills, insight and time to engage in scientific pursuits. This kept the women away from opting for a career in science. The syndrome still persists today, though there is a slight improvement in the scenario.

Under representation of women in science is a pan global phenomenon. Restrictions and reservations for involving women in scientific activities have been there across culture and time. This reservation has resulted in the scanty representation of women in the branch. Scientific professions till the date witness strong gender prejudices and gender divides. This puts the women at the risk of becoming increasingly marginalized in the knowledge society. Equal participation of women is challenged thereby.

\section{WOMEN IN INDIA's SCIENTIFIC LANDSCAPE}

In India, studies conform to the contributions of women scientists in India were invisible. But, today revelations suggest India has a rich history of having plethora women scientists who have made 
landmark contributions to the field of science. The names of Anandibai Joshee, one of the first Indian women doctors qualified to practice western medicine, Janaki Ammal, the Director-General of the Botanical Survey of India (BSI) stand distinct. Ammal's seminal work on medically important and economically valuable plants is a valuable contribution to India's scientific literature. To name a few more, Anna Mani was a lead physicist and meteorologist, Asima Chatterjee was an Indian chemist noted for her work in the fields of organic chemistry and phytochemistry (chemicals derived from plants), Rajeshwari Chatterjee was the first woman engineer from Karnataka, Darshan Ranganathan was known for her work on "pioneering work in protein folding" and "supramolecular assemblies, molecular design, chemical simulation of key biological processes, synthesis of functional hybrid peptides and synthesis of nano tubes.'Indian scientific literature accommodates the name of Maharani Chakravorty who happens to be a molecular biologist starting the maiden scientific inquiry on DNA techniques in Asia and the Far East in 1981.Irrespective of all such glorious heritage of women, public imagination in India undermined and still underestimates women's representation in science and a glass ceiling continues to be erected for the women in the field of science and technology.

\section{OVER VIEW OF LITERATURE ON WOMEN IN SCIENCE}

Compared to the other areas of gender studies and research, researches on women in science are scanty in India. More documentation are on the initiatives taken by the Government and the incentive programmes to promote women's entry into science. Critical studies on the challenges faced by women in this sector are scanty and have not yet got adequate research treatment. A few studies that could be traced in this regard are quoted here.

The SED Report ${ }^{3}$ suggests maximum women scientists are engaged in life sciences while minimum in genetics \& agricultural economics. Women scientists tend to be a deprived class and are discriminated against their male counterparts in the area of science and technology. This discrimination takes place quite openly; there is nothing secret or subtle about it. They are discouraged from seeking admission in certain specializations or handling important projects or attending conferences in India or abroad. Uncertain and long working hours are important factors towards women opting out to take up scientific professions. The scientific agencies fail to provide institutional child-care even if it is a mandate and younger women scientists, are quit harassed with the problems of child-care.

Studies by Rajendra Prasad Jaiswal in 1993; Carol Mukhopadhyay and Susan Seymour, 1994; P. Duraisamy and Malathy Duraisamy, $1998^{4}$ have unanimously reflected on the discrimination against women in science. To the researchers women are in the neglected zone of science and technology which dissuade the young girls to take up the profession. Gupta and Sharma 2002, Kumar2008, Subramanyam1998 ${ }^{\mathbf{5}}$ on the basis of their case studies in universities note organisational and professional rigidities reflective in the social attitudes and engagement of women in the care economy hinder the participation and progress of women in science as a career. Indian National Science Academy, $2004^{6}$ reports that the proportion of women in national laboratories and prestigious universities is less than 15\%, except in DBT and ICMR where the percentage exceeds 25\%. A 2010 research report ${ }^{7}$ by AAUW presents compelling evidence of gender stereotypes and gender bias ingrained in science. The report suggests key barriers to women's entry into STEM include the environmental and social barriers. A study of Kurup, Maithreyi, Kantharaju and Godbole , 2010 of the Indian Academy of Science (IAS) and the National Institute of Advanced Studies (NIAS), Bangalore, explored the reasons of drop out of women from scientific research. Absence of job opportunities, institutional factors and the opaque selection process were the key factors detected by the researchers. Lilavati's Daughters -Women Scientists of India', a collection of essays of about nearly 100 Indian women scientists from India, aims to highlight the issue and seeks remedies for the same. A joint study by WISAT and OWSD titled The Framework on Gender Equality and the Knowledge Society, $2012{ }^{\mathbf{1 0}}$ highlighted the gender imbalance in science and technology. Leon and Velho, $1997^{11}$ express very little is known about the contribution of female researchers to scientific production. However, there are some reports which provide a positive note about women's participation in scientific pursuits. To cite an example the joint report prepared by the British Council, India UK Science \& Innovation Network, India and Department of Science and Technology suggest India fared quite well among six countries namely, South Korea, Brazil, South Africa, USA, EU and Indonesia. ${ }^{12}$ 


\section{INITIATIVES OF THE GOVERNMENT TO BREAK THE GLASS CEILING IN SCIENCE}

Invisibility of women in science as a branch of knowledge, in scientific organisations and in the research and development institutions was detected as a critical area of concern by the government of India. The Government started gearing efforts and formulated multi pronged strategies for mainstreaming women in science and as a part of its gender development programme. The government tried to address the gender parity challenges in Research and Development Sector to erode the missing women concept in the science and technology .It also tried to leverage and utilise the vast talent base of women by accommodating them in science for accelerating the pace of the country's development. Three issues were detected to be surrounding women in science. They were retention, respect and recognition ${ }^{13}$.

Though the concern for accommodating more and more women in science and technology started as early as the publication of the eye opening report of the committee on The Status of Women in India, it took years together for the government to bring it to the level of policy reflection and policy implementation. The Science and Technology Policy, $2003^{14}$ clearly enunciates its commitment to promote the empowerment of women in all science and technology based activities and ensure their full and equal participation. The Department of Science and Technology adopted the Women Component Plan in $2002^{15}$ with a separate allocation for compliance and implementation of various government led programmes under gender budgeting. On the basis of INSA Report $(2004)^{16}$, the Department of Science and Technology formed the Taskforce for Women in Science and the recommendations of the report were presented to the Ministry of Science and Technology in 2009. Now a number of pro women programmes are launched by the Department of Science and Technology to promote gender mainstreaming in science.

A first of its kind fellowship scheme for women scientists was started in 2002, aiming to bridge a break in career that women face in view of family responsibilities. This program has enabled women scientists who are not in fulltime employment to undertake project based activities in the S\&T field.

The scheme is operational in two key areas. These are: according fellowship for research in basic and applied science, and making fellowship provisions for S\&T.

Another promising programme relates to capacity building by imparting training to women in science. This programme is implemented since 2002.Capacity building program of the Department of Science \& Technology (DST) is being implemented by the Patent Facilitating Centre of Technology Information Forecasting \& Assessment Council (TIFAC). The program aims to train women having qualifications in science/ engineering / medicine or allied areas in the area of intellectual property rights (IPR) and their management for a period of one year.

The Science and Technology Policy of the Govt. of India 2003, enunciates a commitment to promote the empowerment of women by accommodating and ensuring better and greater participation of women in S\&T. One of the actions taken was the publication of the INSA report. A Task Force for Women in Science of the Department of Science and Technology (DST Task Force for Women in Science) was also formed. The Task Force came up with a set of recommendations which were presented to the Minister of Science and Technology in 2006. One of the recommendations was to form a Standing Committee of the Government of India for Women in Science. This committee finally came into being in 2009.

Subsequently, the Department of Science \& Technology, Government of India, set up Science and Technology Entrepreneur's park (STEP), Technology Business Incubators (TBIs) Innovation and Entrepreneurship Development Cells (IEDCs) in educational institutions. This is done with a view to promote entrepreneurial skill among young students and to increase their self employability capacity. To nurture the women entrepreneurs, DST has developed over 48 STEPs in the country for women only academic institutes.

A scheme Consolidation of University Research, Innovation and Excellence (CURIE) was launched by DST in 2008, to strengthen the R\&D infrastructure of women-only universities.

Refresher Training Courses for Scientists as Career Advancement Measure has been undertaken by the Department of Science and Technology. The DST presently has a division called 'Science for Equity, Empowerment and Development Division' (SEED). 
The training programme for working women scientists covering multifarious themes in partnership with premier national level institutes has provided an opportunity to over 900 women scientists to upgrade their knowledge base and skills and to keep themselves abreast with the current developments in their field. In 2013, the national Science, Technology and Innovation Policy (STIP) ${ }^{17}$ first stipulated gender parity as a stated goal.

Retention and mobility are the twin issues that plague women scientists. Marriage and family hinder their retention and mobility. In order to retain qualified women employed within the Indian S\&T sector, a new initiative has been launched to increase mobility and retention of employed women scientist in the profession. This is proposed in the 12thfive year plan. The scheme proposes to create 1000 contractual positions with portability within India for creating opportunities for overcoming lateral entry challenges for women. This is expected to tackle the issue of women's non retention and dropout from the scientific R\&D organisations.

DISHA Science Communicators is still another initiative. It is a notion for the women who have the scientific degree and can contribute to popularize science and technology among the masses and stimulate a scientific and technological temper among people through S\&T communications in different languages. The scheme is expected to provide opportunity to:

- Women scientists to work from home/part-time as a science communicator.

- Women scientists to interact closely with media organizations.

- The media specialist to get personal experience to recent developments taking place in our laboratories with a view to enhance their effectiveness in communicating scientific knowledge to the people more meaningfully and effectively.

In the year 2014, Department has restructured all the women specific programmes under one umbrella known as "KIRAN"18 (Knowledge Involvement in Research Advancement through Nurturing). KIRAN is addressing various issues related with women scientists (e.g. unemployment, relocation etc.) and aims to provide opportunities in research, technology development/demonstration, and self-employment etc. KIRAN is also actively involved in taking proactive measures, under the name CURIE (Consolidation of University Research for Innovation and Excellence in Women Universities) to develop state-of-the-art infrastructure in women universities in order to attract, train and retain promising girls students in S\&T domain. In continuation of this, another landmark programme, named as, "Mobility Scheme" has been just launched under KIRAN (Knowledge Involvement in Research Advancement through Nurturing) which is supposed to address relocation issue of women scientists working in regular position in Government Organizations. The Mobility Scheme is aimed to provide an opportunity to women scientists who are facing difficulties in their present job due to relocation (marriage, transfer of husband to any other location within the country, attending ailing parents, and accompanying children studying in different city) and is expected to act as filler while searching other career option at new place. The initiative intends to provide a harmonious environment during early phases of women scientists where they would like to stay active in research in addition to attending and fulfilling other responsibilities in the domestic front. It offers a contractual research award to women scientists and enables them for undertaking independent research.

\section{WOMEn In SCIEnCE TOdaY: A STOCK TAKIng}

Irrespective of so many attractive provisions introduced to attract women for science, gender parity is still a distant dream in science and technology. Glass ceiling is not an imagination but a reality in the scientific profession. Gender divide is reflected through the meagre proportion of women in science education, through the meagre proportion of women constituting human resource in the scientific organisations, through the meagre number of women in scientific leadership roles, meagre number of awardees of scientific fellowships and prestigious scientific awards and prizes. Structural and cultural barriers prevent women to be properly represented and excel in this sector. Many times it is supposed to be a forbidden zone for women. This makes gender mainstreaming agenda non operative in scientific line.

Going by sheer statistics, women's enrolment in science is not negligible in India. A study commissioned by the Indian National Science Academy (INSA) in 2004 found that women constitute more than one-third of total science degree holders but comprised only 15-20 per cent of tenured 
faculty. Immediately after Indian independence the share of women in science education in universities was less than 5\%. By 2012, women's share in science increased to about $43.9 \%$ showing a steep rise. Venkatesh $(2015)^{19}$ noted the number of women in PhDs in science has increased to 37 per cent. Globalisation resulting in a mushrooming of engineering colleges has pushed women's entry into engineering branch, the applied field of science. Now there are about 50\% girls in the engineering colleges. But tragically enough in the top ranking scientific and engineering institutes like IISC, IITs their share is still meagre. Thus, women's share has not reached even 50percent of the total science enrolment. This challenges "Beti Padhao" slogan given by the present Government.

The Inter Press Service News Agency published a report in $2009^{19}$ that revealed that women scientists are sidelined by male-centric selection committees for awards and for appointments to R\&D positions in government funded organisations.

Even after so many lucrative women centric provisions, women are still marginal in the scientific organisations and research institutes of the country. A stock taking made in the lead scientific organisations is presented in Table No. 1.

Table1. Percentage of Women in Various Scientific Research Organisations of India

\begin{tabular}{|c|c|c|}
\hline Name of the Organisation & \%of women scientists in2004 & \%of women scientists in2008 \\
\hline CSIR & 13 & 16.5 \\
\hline DST & & 20.8 \\
\hline DAE & 16.5 & 15 \\
\hline DBT & 31.8 & 27.4 \\
\hline ICMR & 27.3 & 29 \\
\hline DRDO & & 14 \\
\hline DOD & 8.7 & 14.3 \\
\hline ICAR & 8.5 & 7.7 \\
\hline IISC. & 6.6 & \\
\hline
\end{tabular}

Source: Godbole, Rohini M. And Ramakrishna Ramaswamy (2015) Women Scientists in India in Women in Science and Technology in Asia, The Association of Academies and Societies of Sciences in Asia (AASSA), Panmun Education Co., Ltd

The following diagram indicates the share of women in the research organisations of the country.

\section{\%of Women Scientists in2008}

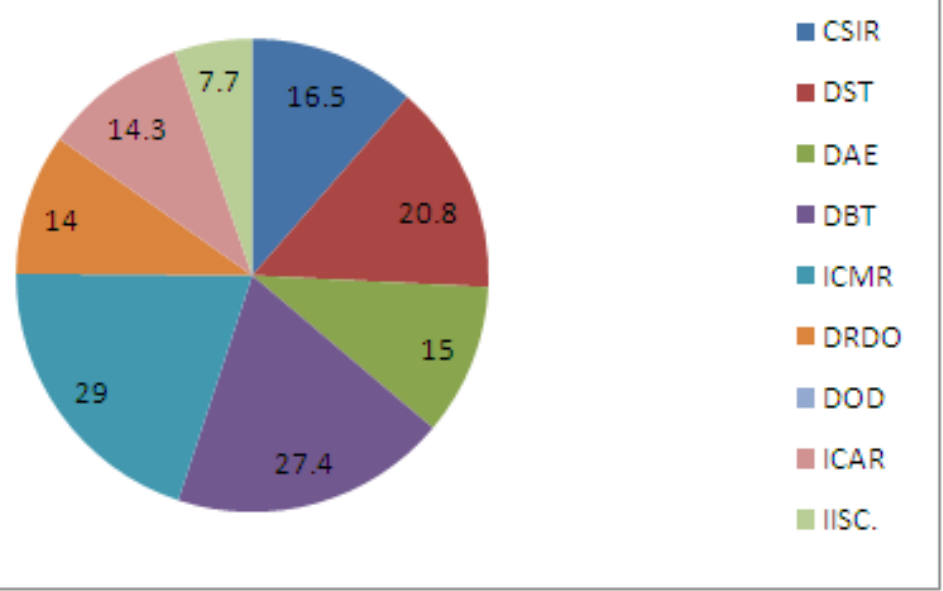

Thus, the above table reveals a clear cut marginalisation and under representation of women in the scientific organisations. Scientific organisations in India have not yet shed their patriarchal structure and functioning style. This is a disgrace to the grand slogan for the empowerment of women through science and technology.

Coming to scientific leadership roles, it is noted that the share of women drops down drastically. This provides a glimpse of male chauvinism prevalent in the Indian scientific organisations. There are a countable number of women who have created a niche in their own scientific organisations. This has become a sensation from time to time. To quote a few examples, Dr. M Lakshmi Kantam became the 
first woman Director of a CSIR lab in the entire seven decade long history of CSIR, when she took over as Director of CSIR-IICT on April 9, 2013.Dr.Manju Sharma after superannuating and completing her tenure as Secretary, Department of Biotechnology in February, 2004, was appointed as Adviser to the Minister of Science \& Technology, a covated position adorned by a woman. The All Indian Institute of Medical Sciences (AIIMS) has had only one woman director Dr Sneh Bhargava in 1984 in its 60-year history given the large number of women in medicine, and this is also true for the Indian Council for Medical Research (ICMR).The prestigious Indian Statistical Institute, founded in the year 1931, has in its history a single woman director. The first woman director of the Indian Institute of Geomagnetism was appointed in 2005, after its establishment as an autonomous institute in 1971. Other institutions that have been headed by women at some time include the National Institute of Immunology, the National Brain Research Centre, and the Institute of Advanced Study in Science and Technology. There are only two women directors: S.K. Pandey at NIT-Puducherry and Dr Latha Pillai at Rajiv Gandhi National Institute of Youth Development.

There has been a steady increase in the absolute numbers of women Principal Investigators, and by 2010 the number was close to $23 \%$ which is again a marginal figure. So this indicates that projects are not easily sanctioned to the women. Their productivity is still a big question mark in the world of science.

The IAS-INSA report $2010^{20}$ points "Even though one of every four scientists in India is a woman the largest pool of them remains at the lower rungs of Science".

A gender-wise breakup of data related to three important national awards, the Shanti Swarup Bhatnagar award, the Young Scientist and National Bio Science award - shows a consistent marginalization of female scientists and technologists. 14 out of 416 Shanti Swaroop Bhatnagar awards have been given to women which highlights the lack of recognition of the excellence of women in STEM. ${ }^{21}$ Of the total 133 people who won the Young Scientist award up to 2009, only 17 were females. Between the years 1999-2003, only two women scientists have received the National Bio Science award instituted by DBT. Out of 395 National Academy of Agricultural Sciences Fellowships only $4 \%$ went to women. Out of the 502 awards and medals given by INSA only 14 (2.8\%) have gone to women. Out of 841 Indian Academy of Sciences Fellowships only 4.6 went to women. Table No.2 projects the gender based distribution of INSA fellowship for 2012.

Table2. Gender distribution of the fellowship for INSA (2012)

\begin{tabular}{|l|l|l|l|}
\hline Subject & Women & Men & Percentage for Women \\
\hline Medical & 17 & 52 & 25 \\
\hline Mathematics & 06 & 64 & 8.5 \\
\hline Physics & 4 & 116 & 3.3 \\
\hline Chemistry & 1 & 117 & 0.08 \\
\hline Plant \& Animal Science & 20 & 200 & 10 \\
\hline Total & 49 & 816 & 5.6 \\
\hline
\end{tabular}

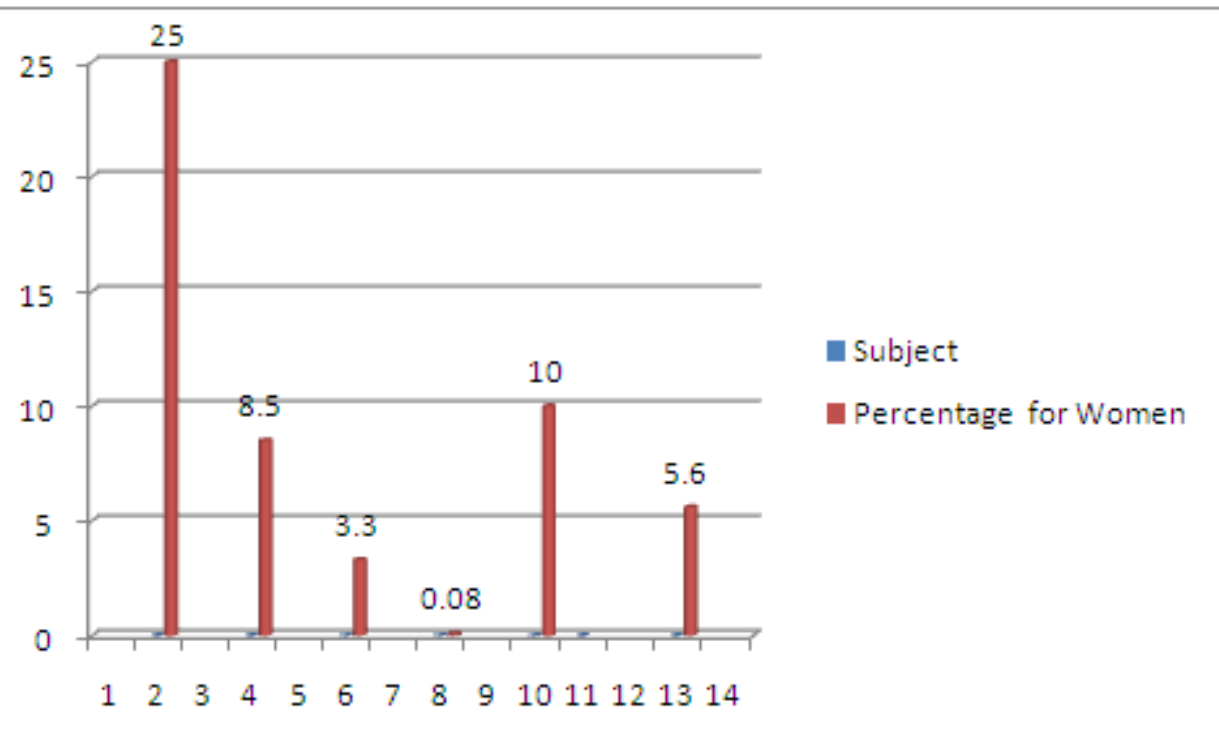




\section{INSIGHTS DRAWN}

The foregoing discussions clearly project gender asymmetry grapples Indian science. Women are the scientific underdogs subdued by their male partners in the professional field. Their entry into science education and science higher education is on rise, but the number does not commensurate to the portfolios occupied them in the scientific hierarchy. Recognition of their seminal contributions to various fields of science need more accolade. They are rarely scientific leaders, but often scientific followers discharging the mechanical stereo typed jobs in the scientific organisations. Apprehensions loom large before the project sponsoring organisations to award projects to women scientists. This is a clear indication of the doubt which still clouds the administrators, organisational heads and sponsoring authorities about the skill, talent and worth of the intellectual calibre of women in science.

Government provisions to inspire women to participate in science education and profession are many. But they remain under the carpet of patriarchal structure and the gender stereotypes prevalent in the society. Public private dichotomy still shrouds the minds of the milieu. Women's traditional reproductive roles mismatch with the productive demands of scientific organisations .Their periodical abstention from the research work due to the pressing demands of rearing the families prevent them to prove their continuity and productivity in an ongoing research. This turns out to be catastrophic for their long term career in science. Overtime work is again a taboo for women in the Indian cultural set up. But, scientific works demand overtime work and as such becomes impracticable for women. Scientific works are more collective and women are more suited for individual works where they can adjust their work with their time. This negates women's association in larger projects. Fellowships are time bound and task driven. In many instances, marriage and family hinder women's output and their commitment to meet the time bound delivery target. This reduces the trust of fellowship awarding organisations. Thus women become the excluded groups in science as a stream and their participation in the knowledge economy is challenged.

However, it can be concluded that a time has come to erode the traditional perception about the impoverished status of women in science. Provisions need a translation into action. For this, the feminist groups, women themselves have to anchor a movement to break the glass ceiling and to overcome the gender divide in science. Without participation rather equal participation of women in science, the knowledge economy cannot be strengthened and the real knowledge empowerment of women cannot take place. For this, the society needs a change in the cultural, perceptual and practice level. Changed perception about the productive role of women, recognition of their skill and capacity, equal participation of gender groups in the care economy can bring a change in the traditional roles of women providing them liberty to participate in scientific endeavours which is recognised as a high level of intellectual pursuit. Further, organisational provisions of flexi timing, work from home facilities, and crèche provisions for children can enable women to be attracted for the scientific line. Further, awarding relaxation in fellowships to women, giving some time relaxation, entrusting responsibilities on them at a higher level of the scientific hierarchy can help for confidence building among women and can make them better performers in science.

\section{REFERENCES}

[1] Merriam Webster Dictionary Definition of Science

[2] Oxford English Dictionary Definition of Innovation

[3] Report on the 'Status of Women Scientists in Science and Technology/ Research and Development Institutions in Delhi" submitted to the National Commission for Women by Society for Environment and Development, http://ncw.nic.in/

[4] Report (2010) Why So Few? Women in Science, Technology, Engineering, and Mathematics, http://www.aauw.org/research/why-so-few/

[5] Kurup, Anitha ()Women Science Professionals in India http://www.iusstf.org/cms/newsi mages/file/women-in-science/National-Institute-of-Advanced-Studies.pdf

[6] Report(2004) Indian National Science Academy ,New Delhi

[7] Report (2010) Why So Few? Women in Science, Technology, Engineering, and Mathematics, op.cit.

[8] IAS-NIAS Research Report (2010) Trained Scientific Women Power: How much We are Losing and Why? Anitha Kurup, Maithreyi R, Kantharaju B and Rohini Godbole 
[9] Godbol, Rohini and Ramaswami, Ram (2008) Lilavati's Daughters, Women in Science, Indian Academy of Science, ias.ac.in.

[10] Report (2012) Women in Global Science and Technology (WISAT) and the Organization for Women in Science for the Developing World (OWSD), the Elsevier Foundation

[11] Kumar,Neelam(2008) Gender and Science in India , S\&T Human Resources, India, Science and Technology, http://www.nistads.res.in

[12] Summary Report (February 12, 2015) Women in Science, Technology, Engineering and Mathematics (STEM) -A case for intervention, British Council, India UK Science \& Innovation Network, India and Department of Science and Technology

[13] Ibid

[14] Science and Technology Policy (2003) Department of Science and Technology, Government of India

[15] A way forward for Gender Mainstreaming of women in Science and Technology Sector (2002) Department of Science and Technology, Government of India, http://www.dst.gov.in/

[16] INSA Report (2004), http://www.insaindia.org/

[17] Science, Technology and Innovation Policy (2013), Department of Science and Technology, Government of India

[18] Knowledge Involvement in Research Advancement through Nurturing (KIRAN), Department of Science and Technology, Government of India

[19] Venkatesh, Sujatha (2015) in Journal Transcience quoted by Jayaraman Gayatri in The secret sexism of Indian science, India Today, June 26, 2015

[20] Report (2009) Challenges in Science-related Careers for Indian Women, released by the Inter Press Service (IPS) in November

[21] IAS-NIAS Research Report (2010) Trained Scientific Women Power: How much we are Losing and Why? Op.cit.

[22] Kumar, Neelam (2008) Gender and Science in India, op.cit. 